\title{
Phytosterols Content in Vegetable Oils of Brazil: Coconut, Safflower, Linseed and Evening Primrose
}

\author{
Simone Alves da Silva ${ }^{1,2^{\star}}$ \\ https://orcid.org/ 0000-0001-6162-3154 \\ Geni Rodrigues Sampaio ${ }^{2}$ \\ https://orcid.org/ 0000-0002-7763-4664
}

\section{Elizabeth Aparecida Ferraz da Silva Torres ${ }^{2}$}

https://orcid.org/ 0000-0002-1012-1418

${ }^{1}$ Adolfo Lutz Institute, Contaminant Centre, Organic Contaminant Core, São Paulo, Brazil; ${ }^{2}$ University of São Paulo USP, School of Public Health, Department of Nutrition, São Paulo, Brazil.

Received: 2019.04.05; Accepted: 2020.02.21.

*Correspondence: simone.silva@ial.sp.gov.br, Tel.: +55-11-30682921 (SAS).

\section{HIGHLIGHTS}

- $\quad \beta$-sitosterol was found in higher concentrations.

- Evening primrose oil presented the highest amounts of phytosterols.

\begin{abstract}
In the last years phytosterols, natural components of plants, have received more attention due to association of their consumption with reducing risk of cardiovascular diseases and cancer. There are several scientific studies about phytosterols in vegetable oils, but they are scarce in unconventional oils. The objective of this research was evaluating the content of phytosterols ( $\beta$-sitosterol, stigmasterol and campesterol) in vegetable oils sold in São Paulo city, in Brazil. The analysis included cold alkaline saponification, derivatization with hexamethyldisilazane and trimethylchlorosilane reagents, and quantification by gas chromatography using flame ionization detection and internal standardization. The quality control parameters indicated that the method was suitable for analysis. Total sterols were between $272.3 \mathrm{mg} \mathrm{kg}^{-1}$ (coconut oil) to $6169.7 \mathrm{mg} \mathrm{kg}^{-1}$ (evening primrose oil). $\beta$-sitosterol was the component found in higher concentrations and evening primrose oil was the most representative in quantity of phytosterols.
\end{abstract}

Keywords: gas chromatography; plant sterols composition; unconventional oils.

\section{INTRODUCTION}

Oils and fats are good sources of nutritional energy to humans, conferring taste, consistency, and stability on food. Also take part in some cellular functions: they are structural components of the membranes, responsible for the transport and absorption of fat-soluble vitamins, precursors of hormones, and provide essential fatty acids [1]. Cold-pressed vegetable oils have these functions especially unconventional vegetable oils, like safflower, coconut, evening primrose, and linseed. They have biologically active lipids like sterols which provide health benefits, and diseases prevention $[2,3]$.

Triacylglycerols are the main components of the vegetable oils, corresponding to $95-98 \%$ of total lipids. The remaining percentage contains monoacylglycerols, diacylglycerols, free fatty acids, and other minor components in the unsaponifiable fraction, like sterols that are in greater quantity in this fraction [4]. 
Phytosterols are natural components of plants, found in free and esterified forms. More than 100 different phytosterols were identified in vegetable foods, and they have similar chemical structures with cholesterol, with suchlike biological functional $[5,6]$.

There are several health benefits related to the phytosterols consumption, including reduction of cholesterol absorption, reduction of low-density lipoprotein (LDL), effects against inflammations and cancer [6-9].

Maki and coauthors [10] studied the inclusion of $1.8 \mathrm{~g}$ of phytosterols per day in patients with primary hypercholesterolemia, associated with a healthy diet, and this intake promoted favorable changes in atherogenic process, likely total cholesterol, no-HDL, and triacylglycerols. In children with hypercholesterolemia, the LDL was significantly reduced [11].

The Brazilian Society of Cardiology recognizes the impact of phytosterols on hypercholesterolemia, with excellent results in multiple controlled clinical trials [12]. According to Dumolt and Rideout [9], plant sterols may interfere with the cholesterol and triacylglycerols absorption, as well as modulating the ability in lipidregulating genes through the activation of the liver $X$ receptor (LXR).

Some studies have reported sterols's action suggesting reduction of cancer, with associations of $\beta$ sitosterol and stigmasterol to inhibit cancer cells in esophageal tissues, ovaries, breast, colon, and prostate $[6,13]$.

The most common phytosterols found in food are $\beta$-sitosterol, stigmasterol, and campesterol. $\beta$-sitosterol is plenty, and others are present in lower concentrations. The main sources in vegetable foods are nuts, grains, seeds, legumes, and vegetable oils $[13,14]$. Sterols composition is specific for each oil category, with a characteristic relative ratio, so the sterols can be used for providing characterization and identity of oils [15].

The analysis of phytosterols generally includes several steps, as lipid extraction, alkaline saponification, derivatization, and chromatographic quantification [4]. In the AOCS official method [16], sample is saponified with alkali reagent, phytosterols are extracted with organic solvent, and compounds have been separated by thin-layer chromatography; however, this methodology spend more time and use a lot of samples and reagents, so authors have been adopted assays in smaller scales [17]. The quantification systems include liquid chromatography, using an ultraviolet-visible detector, fluorescence or mass spectrometer with atmospheric pressure chemical ionization (APCI) mode [18-20], or gas chromatography (GC) with flame ionization (FID) or mass detectors [14,15,21-23].

Codex Stan 210 establishes the quality and identity standards of coconut and safflower oils, including phytosterols, but this reference does not report parameters to evening primrose and linseed oils [24]. Furthermore, studies about the phytosterols content in unconventional oils are limited in the literature. As the survey of this data could be important, especially as a quality parameter for these products, the objective of this work was to evaluate a method for the quantification the phytosterols, $\beta$-sitosterol, stigmasterol, and campesterol, in vegetable oils and to measure the content in coconut, safflower, evening primrose and linseed oils commercialized in São Paulo city, Brazil.

\section{MATERIAL AND METHODS}

\section{Samples}

Four kinds of cold-pressed vegetable oils were studied, with different brands and lots, 15 of coconut oils (Cocos nucifera L.), 9 of safflower oils (Carthamus tinctorius L.), 3 of evening primrose oils (Oenothera biennis L.), and 12 of linseed oils (Linum usitatissimum L.), totaling 39 samples. Oils used in this study were purchased from local market and drugstores in São Paulo city, Brazil.

\section{Chemicals}

Potassium hydroxide $(\mathrm{KOH})$ was analytical grade. The solvents were HPLC grade: $\mathrm{n}$-hexane, and ethanol (Merck, Darmstadt, Germany). Deionized water was obtained with the Milli-Q purification system (Millipore, Bedford, MA, USA). The derivatizing reagent, hexamethyldisilazane:trimethylchlorosilane (3:1) (Sylon HT Kit) was obtained from Supelco (PN 3-3046; Bellefonte, PA, USA).

The standards were obtained from Sigma-Aldrich (St. Louis, MO, USA): stigmasterol (PN S2424; purity $\sim 95 \%$ ), $\beta$-sitosterol (PN S1270; purity 95 \%), campesterol (PN C5157; purity 65\%), and 5a-cholestane (PN C8003; purity 97\%; internal standard).

Individual solutions of phytosterols were prepared in n-hexane with a concentration of $400 \mu \mathrm{gL} \mathrm{m}^{-1}$ (campesterol and stigmasterol) and $1000 \mathrm{\mu g} \mathrm{mL}^{-1}$ ( $\beta$-sitosterol). So, a working solution with three phytosterols was prepared in $\mathrm{n}$-hexane, with a concentration of $200 \mu \mathrm{g} \mathrm{mL}$ 
$\mu \mathrm{gL}^{-1}$ ( $\beta$-sitosterol), and used to analytical curve preparation. The $5 \alpha$-cholestane was prepared in $\mathrm{n}$-hexane (concentration $200 \mu \mathrm{g} \mathrm{mL}^{-1}$ ), and used as internal standard (IS).

\section{Phytosterols analysis}

The method was based on Saldanha and coauthors [21], with some modification (internal standardization using $5 \alpha$-cholestane).

\section{Saponification and extraction of unsaponifiable material of phytosterols}

$150 \mathrm{mg}$ of the oil was weight in a $50 \mathrm{~mL}$ centrifuge tube and $100 \mu \mathrm{L}$ of IS solution and $10 \mathrm{~mL}$ of $15 \%$ $\mathrm{KOH}$ ethanolic solution were added. The tube was sealed and the saponification was performed for $22 \mathrm{~h}$ in the dark at room temperature. Then, $10 \mathrm{~mL}$ of deionized water and $10 \mathrm{~mL}$ of $\mathrm{n}$-hexane were added and vigorously mixing on a vortex. After separation of phases, the $n$-hexane was removed to another tube. The procedure was repeated three times (totaling $40 \mathrm{~mL}$ of $\mathrm{n}$-hexane), and the combined fractions were evaporated under nitrogen stream until dryness [25].

\section{Phytosterol derivatization}

The dried unsaponified material was derivatized with $100 \mu \mathrm{L}$ of silylating agent (Sylon HT Kit) for $2 \mathrm{~h}$ in the dark at room temperature. After that, the reagent was evaporated under nitrogen stream and the residue was dissolved in $1.0 \mathrm{~mL}$ of $\mathrm{n}$-hexane. The solution was subjected to centrifugation at $5,000 \mathrm{rpm}$ for $5 \mathrm{~min}$, and the upper phase was then transferred into vials suitable for GC-FID analysis [26].

\section{Chromatographic conditions in GC-FID}

A GC-2010 gas chromatograph equipped with a split/splitless injector and a flame ionization detector (Shimadzu, Kyoto, Japan) was used with a capillary silica column VF-5ms (30 m x $0.25 \mathrm{~mm} \times 0.25 \mu \mathrm{m}$; Varian) under programmed conditions: injector temperature $290^{\circ} \mathrm{C}$, detector temperature $350{ }^{\circ} \mathrm{C}$, hydrogen as carrier gas with a constant flow of $1.0 \mathrm{~mL} \mathrm{~min}^{-1}$, injection volume $1 \mu \mathrm{L}$, split 1:20, oven temperature: 230$264^{\circ} \mathrm{C}$ at $2^{\circ} \mathrm{C} \min ^{-1}, 264^{\circ} \mathrm{C}$ for $5 \mathrm{~min}, 264-275^{\circ} \mathrm{C}$ at $1^{\circ}{ }^{\circ} \mathrm{C} \min ^{-1}, 275^{\circ} \mathrm{C}$ for $6 \mathrm{~min}$.

All data were collected by the GC Solution software (Shimadzu). The compounds were identified by comparing the retention times with the individual standards. Internal standardization was employed to quantification, by the ratio between the concentration and peak areas of phytosterols and IS. The concentration was expressed as $\mathrm{mg} \mathrm{kg}^{-1}$ of oil.

\section{Quality control of phytosterol method}

Tests were performed to select $5 \alpha$-cholestane as IS and parameters were evaluated for methodology verification. Limits of detection (LOD) and quantification (LOQ) were calculated for each phytosterol considering the signal-to-noise ratio of 3:1 and 10:1, respectively. The linearity of the standard curve was checked through square correlation coefficients $\left(\mathrm{r}^{2}\right)$ at triplicate determinations of six different concentrations of each sterol. Precision and accuracy were evaluated with a reference sample of the International Olive Oil Council (IOC), with the following composition: $90 \%$ lampante olive oil and $10 \%$ palm olein (COI CHEM/2015, Proficiency Testing, Madrid, Spain).

\section{RESULTS}

\section{Methodology verification - Results of quality control}

Figure 1 shows a chromatogram for a commercial evening primrose oil and phytosterol standards. Coefficients related to the verification of the method are in Table 1. To check the linearity of the method, an analytical curve for each phytosterol was prepared in six different concentrations: campesterol, and stigmasterol (range 5.0 to $200.0 \mu \mathrm{g} \mathrm{mL}^{-1}$ ), and $\beta$-sitosterol (range 12.5 to $500 \mu \mathrm{g} \mathrm{mL}^{-1}$ ), by the correlation between phytosterol concentrations and IS concentration versus areas of phytosterols and area of the IS. The angular and linear coefficients were estimated by regression using the simple least squares method and are presented in Table 1. Good linearity was found, with $r^{2}$ values upper than 0.998. The LOD and LOQ values indicating that the method was sensitive to the suggested proposal (Table 1). 

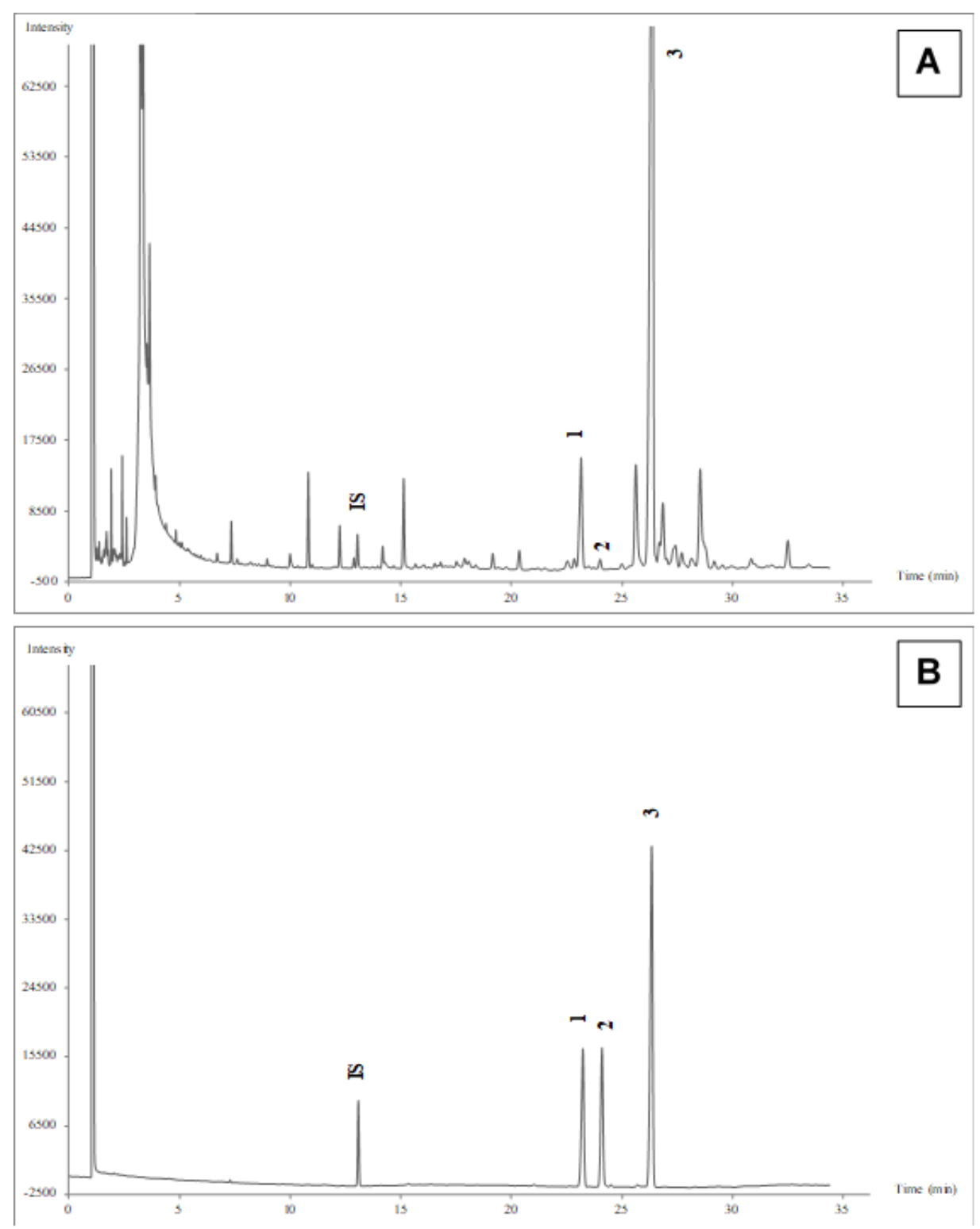

Figure 1. Chromatograms obtained by GC-FID analysis (A) sample of evening primrose oil. IS: $5 \alpha$-cholestane; 1 campesterol; 2 - stigmasterol; 3 - $\beta$-sitosterol; (B) mixture of phytosterols standards. IS: $5 \alpha$-cholestane $\left(30 \mu \mathrm{gL} \mathrm{m}^{-1}\right) ; 1$ campesterol $\left(100 \mu \mathrm{g} \mathrm{mL}^{-1}\right) ; 2$ - stigmasterol $\left(100 \mu \mathrm{g} \mathrm{mL}^{-1}\right) ; 3$ - $\beta$-sitosterol $\left(250 \mu \mathrm{g} \mathrm{mL}^{-1}\right)$.

The performance of the method was evaluated with a reference sample sent by IOC. Results were in \% of total phytosterols $(4.52,1.53$, and $85.66 \%$, respectively for campesterol, stigmasterol and $\beta$-sitosterol) and were calculated in $\mathrm{mg} \mathrm{kg}^{-1}$ (unit measured), considering the total analytes presented in the report (1284 $\mathrm{mg} \mathrm{kg}^{-1}$ ). The precision was adequate, with RSD $<10 \%$, and the mean values were within the acceptable range for each component (Table 1).

Table 1. Coefficients related to the verification of the method for phytosterols at different concentrations.

\begin{tabular}{lccc}
\hline & Campesterol & Stigmasterol & $\beta$-sitosterol \\
\hline Retention time (min) & 23.1 & 24.0 & 26.2 \\
Inclination (a) & 0.9436 & 0.8946 & 0.9783 \\
Intercept (b) & -0.0846 & -0.0658 & -0.1992 \\
$\mathrm{r}^{2}$ & 0.9989 & 0.9994 & 0.9992 \\
Limit of detection $\left(\mathrm{mg} \mathrm{kg}^{-1}\right)$ & 10.0 & 10.0 & 10.0 \\
Limit of quantification $\left(\mathrm{mg} \mathrm{kg}^{-1}\right)$ & 30.0 & 30.0 & 30.0 \\
IOC sample $\left(\mathrm{mg} \mathrm{kg}^{-1}\right)^{\mathrm{a}}$ & $60.5 \pm 0.9$ & $20.7 \pm 1.3$ & $1098.3 \pm 3.4$ \\
Recovery $(\%)^{\mathrm{b}}$ & 104.2 & 104.8 & 99.9 \\
\hline
\end{tabular}

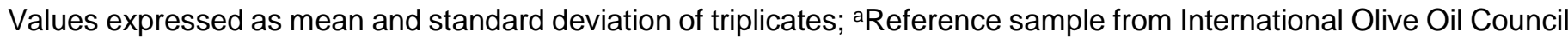
(IOC) sent in 2015. Ranges acceptable: $54.6-61.5 \mathrm{mg} \mathrm{kg}^{-1}$ for campesterol, $16.6-22.9 \mathrm{mg} \mathrm{kg}^{-1}$ for stigmasterol, and $1091.0-1108.7 \mathrm{mg} \mathrm{kg}^{-1}$ for $\beta$-sitosterol; becoveries calculated using the means of IOC ranges. 


\section{Analysis of phytosterols in commercial samples}

The phytosterols analyses were carried out after the confirmation of oil identity by the fatty acid profile, described in Silva and coauthors [2]. Table 2 presents the results of phytosterols (campesterol, stigmasterol, and $\beta$-sitosterol) in unconventional vegetable oils.

Table 2. Phytosterols content $\left(\mathrm{mg} \mathrm{kg}^{-1}\right)$ in vegetable oils.

\begin{tabular}{cccccc}
\hline & & Campesterol & Stigmasterol & B-sitosterol & Total \\
\hline Coconut & Mean & 48.3 & 109.3 & 267.8 & 425.4 \\
$(\mathrm{n}=15)$ & Minimum & 29.9 & 74.5 & 167.9 & 272.3 \\
& Maximum & 62.8 & 136.5 & 337.6 & 535.8 \\
Safflower & Mean & 244.3 & 158.1 & 1020.8 & 1423.2 \\
$(\mathrm{n}=9)$ & Minimum & 198.8 & 136.4 & 856.9 & 1192.1 \\
& Maximum & 382.3 & 222.3 & 1431.2 & 2035.7 \\
Evening & Mean & 531.4 & 43.2 & 5450.2 & 6024.8 \\
primrose & Minimum & 512.1 & 35.1 & 5183.4 & 5742.3 \\
$(\mathrm{n}=3)$ & Maximum & 552.0 & 47.7 & 5604.6 & 6169.7 \\
& Mean & 624.1 & 176.6 & 1472.8 & 2273.4 \\
Linseed & Minimum & 481.0 & 128.2 & 1109.4 & 1725.7 \\
$(\mathrm{n}=12)$ & Maximum & 825.4 & 234.4 & 2012.9 & 3072.6 \\
\hline
\end{tabular}

Mean values $(n=2)$; Total: sum of stigmasterol, campesterol, and $\beta$-sitosterol.

Among the oils studied, $\beta$-sitosterol was the component found in higher concentrations, ranging from 167.9 to $337.6 \mathrm{mg} \mathrm{kg}^{-1}$ in coconut oils, from 856.9 to $1431.2 \mathrm{mg} \mathrm{kg}^{-1}$ in safflower, 5183.4 to $5604.6 \mathrm{mg} \mathrm{kg}^{-1}$ of evening primrose, and 1109.4 to $2012.9 \mathrm{mg} \mathrm{kg}^{-1}$ in linseed oils. The phytosterol with lower concentration in safflower, linseed, and evening primrose oils was stigmasterol, while in coconut oils it was campesterol.

\section{DISCUSSION}

The choice of $5 \alpha$-cholestane as internal standard was made after tests performed. This IS was sufficiently separated from other compounds of interest and the retention time $(13.1 \mathrm{~min})$ was adequate for the analysis. According to Islam and coauthors [6], four IS are more commonly used for phytosterol analysis: $5 \alpha-$

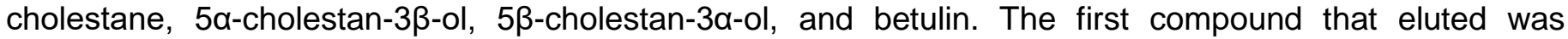
campesterol, followed by stigmasterol, and $\beta$-sitosterol (Figure 1).

For coconut oils, Martins and coauthors [8] reported ranges for stigmasterol and campesterol between 143.4-144.8 mg kg-1 and 57.1-58.6 mg kg-1. These results were similar to those found in this study (respectively $74.5-136.5 \mathrm{mg} \mathrm{kg}^{-1}$ and $29.9-62.8 \mathrm{mg} \mathrm{kg}^{-1}$ ). The levels in safflower oils were similar to those described by Firestone [27]: stigmasterol: $136-254 \mathrm{mg} \mathrm{kg}^{-1}$, campesterol: $193-344 \mathrm{mg} \mathrm{kg}^{-1}$, and $\beta$-sitosterol: $842-1320 \mathrm{mg} \mathrm{kg}^{-1}$. In linseed oils, the total percentage for stigmasterol, campesterol, and $\beta$-sitosterol were respectively 8,27 , and $65 \%$, similar to those found by Tańska and coauthors [28]. The mean value for $\beta$ sitosterol (1472.8 $\mathrm{mg} \mathrm{kg}^{-1}$ ) was very similar to results by Szterk and coauthors [22] (1625 mg kg-1).

Evening primrose oils were considered the best source of phytosterols, with an average value 6024.8 $\mathrm{mg} \mathrm{kg}^{-1}$. $\beta$-sitosterol was the principal phytosterol $\left(5450.2 \mathrm{mg} \mathrm{kg}^{-1}\right)$, followed by campesterol $\left(531.4 \mathrm{mg} \mathrm{kg}^{-1}\right)$, and stigmasterol $\left(43.2 \mathrm{mg} \mathrm{kg}^{-1}\right)$. Szterk and coauthors [22] found values of $6458 \mathrm{mg} \mathrm{kg}^{-1}$ for $\beta$-sitosterol and $65 \mathrm{mg} \mathrm{kg}^{-1}$ for stigmasterol, similar to our data. So, among the oils evaluated, the evening primrose was the most representative in the total quantity of phytosterols.

Figure 2 presents phytosterols results in eight different brands and lots. Results show a high variation in phytosterols levels among different lots of the same brand. $44 \%$ of the evaluated brands presented equal lots in all parameters evaluated. The brands that the concentrations presented statistically similar values were C (coconut oil), D (safflower oil), B and F (linseed oils). Unconventional oils usually are cold-pressed and have high aggregate value. By presenting higher prices, they may be auspicious to adulteration with the intention of potential profit. Generally, other oils with lower nutritional and commercial value are added, which can result in economic losses and reduced health benefits $[2,29]$. Thus, the evaluation of sterol may have consequences for quality control and authentication, since each vegetable oil has unique sterol composition [30]. 

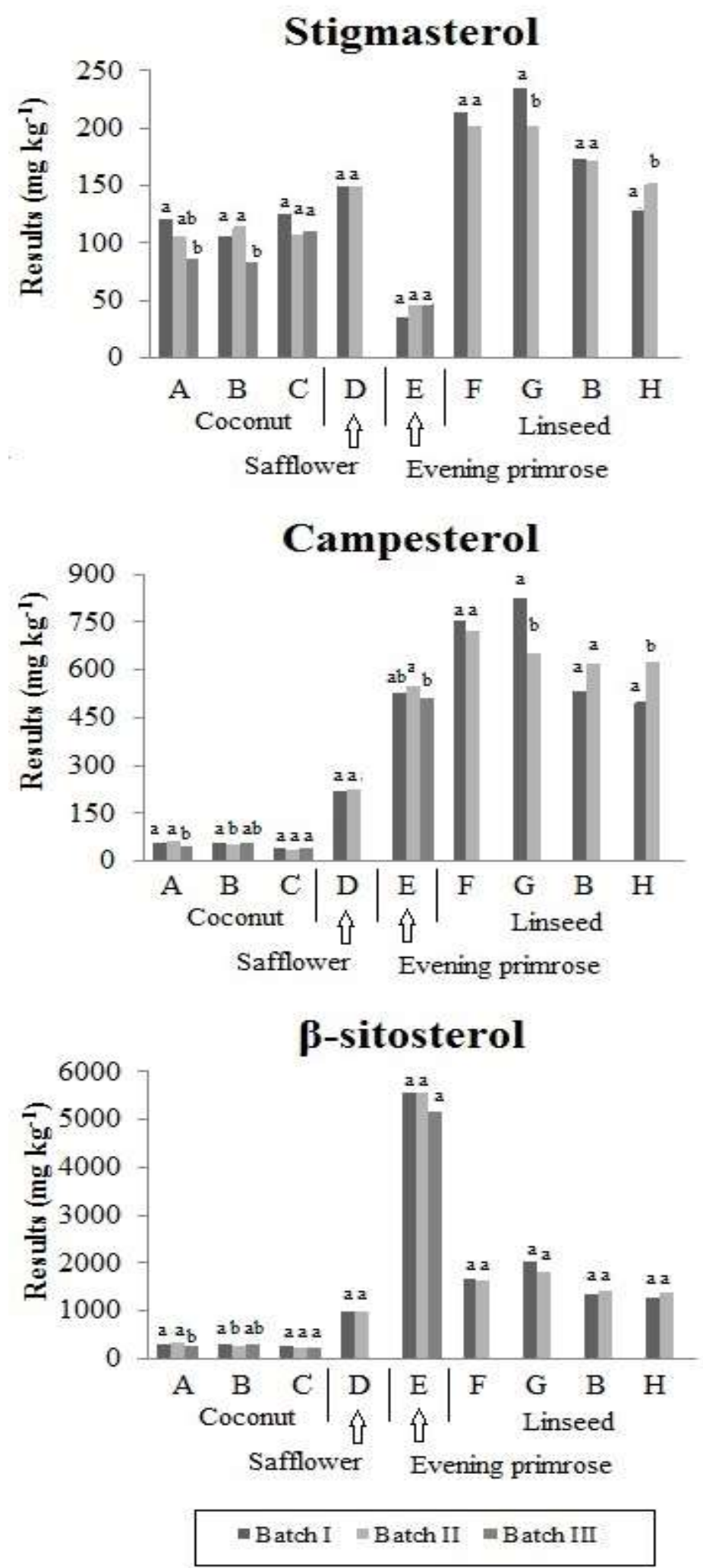

Figure 2. Phytosterols levels in different batches and brands of vegetable oils. Different letters in a brand indicate a significant difference between batches (Student t-test, $p<0.05$ ).

\section{CONCLUSION}

The method applied could be considered suitable for quantitative analysis of phytosterols since it was linear within the range of concentrations investigated, and presented sensitivity, precision, and accuracy. $\beta$ sitosterol was the principal component, found in higher concentrations. The phytosterol with lower results was stigmasterol for safflower, linseed, and evening primrose oils, while for coconut oils was campesterol. Evening primrose was the most representative oil in the total phytosterols amounts $\left(6024.8 \mathrm{mg} \mathrm{kg}^{-1}\right)$, with $90 \% \beta$-sitosterol contribution. A statistical evaluation of different brands shows that four oils presented similar 
values for all components. The results generated in this study can be used as a phytosterols database for vegetable oils from unconventional sources since information about these oils is limited.

Funding: This research was funded by São Paulo Research Foundation (FAPESP), grant number 2014/12604-0.

Acknowledgments: The authors are grateful to researcher Dr. Sabria Aued Pimentel (Adolfo Lutz Institute) for collaboration, and the partnership of Adolfo Lutz Institute.

Conflicts of Interest: The authors declare no conflict of interest.

\section{REFERENCES}

1. Perini JADL, Stevanato FB, Sargi SC, Visentainer JEL, Dalalio MMDO, Matshushita M, et al. Ácidos graxos poliinsaturados n-3 e n-6: metabolismo em mamíferos e resposta imune. Rev Nutr. 2010;23(6):1075-86. doi:10.1590/S1415-52732010000600013.

2. Silva SA, Torres EAS, de Almeida AP, Sampaio GR. Polycyclic aromatic hydrocarbons content and fatty acids profile in coconut, safflower, evening primrose and linseed oils. Food Chem. 2018;245:798-805. doi:10.1016/j.foodchem.2017.11.109.

3. Teh SS, Birch J. Physicochemical and quality characteristics of cold-pressed hemp, flax and canola seed oils. J Food Compost Anal. 2013;30(1):26-31. doi:10.1016/j.jfca.2013.01.004.

4. Sakouhi F, Absalon C, Flamini G, Cioni PL, Kallel H, Boukhchina S. Lipid components of olive oil from Tunisian Cv. Sayali: Characterization and authenticity. C R Biol. 2010;333(9):642-8. doi:10.1016/j.crvi.2010.05.001.

5. Liu S, Ruan H. A highly sensitive quantification of phytosterols through an inexpensive derivatization. Chem Phys Lipids. 2013;166:18-25. doi:10.1016/ j.chemphyslip.2012.12.002.

6. Islam MA, Jeong BG, Jung J, Shin EC, Choi SG, Chun J. Phytosterol determination and method validation for selected nuts and seeds. Food Anal Methods. 2017;10(10):3225-34. doi:10.1007/s12161-017-0877-3.

7. Marangoni F, Poli A. Phytosterols and cardiovascular health. Pharmacol Res. 2010;61(3):193-9. doi:10.1016/j.phrs.2010.01.001.

8. Martins CM, Fonseca FA, Ballus CA, Figueiredo-Neto AM, Meinhart AD, de Godoy HT, et al. Common sources and composition of phytosterols and their estimated intake by the population in the city of São Paulo, Brazil. Nutrition. 2013;29(6):865-71. doi:10.1016/j.nut.2012.12.017.

9. Dumolt JH, Rideout TC. The lipid-lowering effects and associated mechanisms of dietary phytosterol supplementation. Curr Pharm Des. 2017;23(34):5077-85. doi:10.2174/1381612823666170725142337.

10. Maki KC, Lawless AL, Reeves MS, Kelley KM, Dicklin MR, Jenks BH, et al. Lipid effects of a dietary supplement softgel capsule containing plant sterols/stanols in primary hypercholesterolemia. Nutrition. 2013;29(1):96-100. doi:10.1016/j.nut.2012.05.002.

11. Garoufi A, Vorre S, Soldatou A, Tsentidis C, Kossiva L, Drakatos A, et al. Plant sterols-enriched diet decreases small, dense LDL-cholesterol levels in children with hypercholesterolemia: a prospective study. Ital J Pediatr. 2014;40(1):42. doi:10.1186/1824-7288-40-42.

12. Xavier HT, Izar MC, Faria Neto JR, Assad MH, Rocha VZ, Sposito AC, et al. V Diretriz Brasileira de Dislipidemias e Prevenção da Aterosclerose. Arq Bras Cardiol. 2013;101(4):1-20. doi:10.5935/abc.2013S010.

13. Shahzad N, Khan W, Shadab MD, Ali A, Saluja SS, Sharma S, et al. Phytosterols as a natural anticancer agent: Current status and future perspective. Biomed Pharmacother. 2017;88:786-94. doi:10.1016/j.biopha.2017.01.068.

14. Srigley CT, Haile EA. Quantification of plant sterols/stanols in foods and dietary supplements containing added phytosterols. J Food Compost Anal. 2015;40:163-76. doi:10.1016/j.jfca.2015.01.008.

15. Bezerra KDS, Antoniosi Filho NR. Characterization and quantification by gas chromatography of free steroids in unsaponifiable matter of vegetable oils. J Braz Chem Soc. 2014;25(2):238-45. doi: 10.5935/0103-5053.20130288.

16. AOCS - American Oil Chemists' Society. AOCS Official Method Ch 6-91 - Determination of the composition of the sterol fraction of animal and vegetable oils and fats by TLC and capillary GLC.In: Firestone (Ed.) Official Methods and Recommended Practices of the AOCS, 6th ed, Urbana, IL: AOCS; 2009.

17. Al-Ismail KM, Alsaed AK, Ahmad R, Al-Dabbas M. Detection of olive oil adulteration with some plant oils by GLC analysis of sterols using polar column. Food Chem. 2010;121(4):1255-9. doi:10.1016/j.foodchem.2010.01.016.

18. Flakelar CL, Prenzler PD, Luckett DJ, Howitt JA, Doran G. A rapid method for the simultaneous quantification of the major tocopherols, carotenoids, free and esterified sterols in canola (Brassica napus) oil using normal phase liquid chromatography. Food Chem. 2017;214:147-55. doi:10.1016/j.foodchem.2016.07.059.

19. Ito M, Ishimaru M, Shibata $T$, Hatate H, Tanaka R. High-performance liquid chromatography with fluorescence detection for simultaneous analysis of phytosterols (stigmasterol, $\beta$-sitosterol, campesterol, ergosterol, and fucosterol) and cholesterol in plant foods. Food Anal Methods. 2017;10(8):2692-9. doi:10.1007/s12161-017-08412. 
20. Yuan C, Xie Y, Jin R, Ren L, Zhou L, Zhu M, Ju Y. Simultaneous analysis of tocopherols, phytosterols, and squalene in vegetable oils by high-performance liquid chromatography. Food Anal Methods. 2017;10(11):3716-22. doi:10.1007/s12161-017-0927-x.

21. Saldanha T, Sawaya ACHF, Eberlin MN, Bragagnolo N. HPLC separation and determination of 12 cholesterol oxidation products in fish: comparative study of RI, UV, and APCI-MS detectors. J Agric Food Chem. 2006;54(12):4107-13. doi: 10.1021/jf0532009.

22. Szterk A, Roszko M, Sosińska E, Derewiaka D, Lewicki PP. Chemical composition and oxidative stability of selected plant oils. J Am Oil Chem Soc. 2010;87(6):637-45. doi:10.1007/s11746-009-1539-4.

23. De la Paz SM, Fernández-Arche A, Ángel-Martín M, García-Giménez MD. The sterols isolated from evening primrose oil modulate the release of proinflammatory mediators. Phytomedicine. 2012;19(12):1072-6. doi:10.1016/j.phymed.2012.06.008.

24. Codex Alimentarius. Codex Stan 210 - Codex standards for named vegetable oils. Rome: Codex Alimentarius; 2015. Available from: http://www.fao.org/fao-who-codexalimentarius/codex-texts/list-standards/en/

25. Dionisi F, Golay PA, Aeschlimann JM, Fay LB. Determination of cholesterol oxidation products in milk powders: methods comparison and validation. J Agric Food Chem. 1998;46(6):2227-33. doi:10.1021/jf9710600.

26. Johnson L, Dutta PC. Characterization of side-chain oxidation products of sitosterol and campesterol by chromatographic and spectroscopic methods. J Amer Oil Chem Soc. 2003;80(8):767-76.

27. Firestone D. Physical and chemical characteristics of oils, fats and waxes. Champaign: AOCS Press; 2005.

28. Tańska M, Roszkowska B, Skrajda M, Dąbrowski G. Commercial cold pressed flaxseed oils quality and oxidative stability at the beginning and the end of their shelf life. J Oleo Sci. 2016;65(2):111-21. doi:10.5650/jos.ess15243.

29. Azadmard-Damirchi S, Torbati M. Adulterations in some edible oils and fats and their detection methods. J Food Qual Hazards Control. 2015;2(2):38-44.

30. Broughton R, Ruíz-Lopez N, Hassall KL, Martínez-Force E, Garcés R, Salas JJ, et al. New insights in the composition of wax and sterol esters in common and mutant sunflower oils revealed by ESI-MS/MS. Food Chem. 2018;269:70-9. doi:10.1016/j.foodchem.2018.06.135.

(C) 2020 by the authors. Submitted for possible open access publication under the terms and conditions of the Creative Commons Attribution (CC BY NC) license (https://creativecommons.org/licenses/by-nc/4.0/). 